\title{
STRUCTURAL AND SPATIAL (RE) ORGANIZATION OF THE INDUSTRY IN THE REPUBLIC OF MACEDONIA IN THE 21ST CENTURY
}

\author{
DOI: http://dx.doi.org/10.18509/GBP.2017.36 \\ UDC: 911.374.4:66-043.86(497.7)"21"
}

\section{Biljana Apostolovska Toshevska Marija Ljakoska}

University of "Ss Cyril and Methodius" - Skopje, Faculty of natural sciences and mathematics, Institute of geography, Macedonia

\begin{abstract}
The structural and spatial directions of the industrial development in the country took a different dimension in the $21^{\text {st }}$ century. The entrance of foreign investments created conditions for the activation of certain industrial sectors. While starting from the concept of balanced economic development, economic, social and demographic sustainability of the territory of the Republic of Macedonia, a greater number of industrial zones were built as defined spatial forms for the development of the industry. Specifically, in addition to the existing industrial cores, were built about 15 industrial, technological development zones in which investors have shown or may show interest to invest mainly due to the conditions and incentives offered to invest.

This paper aims to stress out such changes forming economic and geographical picture of the current structural and spatial characteristics of the industry that would be the basis for monitoring the economic, demographic and social dimension of the industry and its importance to sustainable development of the area in which it acts.
\end{abstract}

Keywords: Macedonia, industry, investments, sustainable development.

\section{INTRODUCTION}

The beginnings of the industrial production in Macedonia were recorded in the second half of the $19^{\text {th }}$ century, a hundred years later than the beginning of the process of industrialization in the world. The factors that enabled start of the industrial production were the product of the existing socio-economic conditions. More precisely, in addition was the transition from sipahi into a chiflik system, the increased agricultural production and the export of surpluses to the market and the acceptance of industrial crops. This way, they have created the basis of raw materials for the development of the first forms of industry [10].

More significant growth and development of the industry was experienced after the Second World War. Firstly, from 1945 to 1951 starting with the renewal of the existing facilities and the establishment of smaller industrial enterprises [11], then from 1957 to 1967 was recorded some intensive industrial facilities building, mainly from among the textile, food processing, metal processing industry, non-metal industry and metallurgy. This is the period when was implemented the greatest industrialization in the country. From 1968 to 1980 started the process of modernization of industrial facilities [12]. The growth of the industry was also recorded in the next ten years. The number of employees from 1945-50 to 1985-89 was increased by 13 times, and only in the period from 195155 to $1961-65$, the number of employees in the industry increased by $170 \%$ [1]. Until 1990 it was made an increased effort for achieving more intensive industrialization of the country, but however, indicators suggest that the desired results were not achieved, 
mainly because of intensifying of the basic and raw orientated industries instead of the necessary investments in the labor-intensive and modern industries [12].

The dynamics of the industry in Macedonia after 1990 were directly affected by the current socio-economic and political events in this period. When the Republic of Macedonia become independent, the redefinition of the production capacity of the industrial enterprises, the redefinition of the size and type of the market, the implementation of the privatization, the bankruptcy processes of several industrial enterprises, hindered the supply of raw materials, the embargo by Greece (in 1994), were the creators of the industrial production in this period. The industrial production index after 1990, compared to the previous period, drastically decreased. From 1990-1994 to 1995-1999, the number of employees in the industry decreased by $31.4 \%$. After 1991, the industry was followed by the process of stagnation and decline. It is the period of transition when a number of factories stopped working, while mines such as "Zletovo", "Sasa", "Toranica", "Buchim" and others were closed by the end of 2004. Due to the evident difficulties and experiencing the industry as the most important economic branch in the country, the direction of the further development of the industry was focused towards the efforts for attracting foreign capital that would enable the revitalization of the industrial production.

\section{STRUCTURAL AND SPATIAL ORGANIZATION OF THE INDUSTRY IN THE REPUBLIC OF MACEDONIA IN THE $21^{\text {st }}$ CENTURY}

When Macedonia become an independent country, the process of transformation from one system to another was the reason for the intensive changes from economic, social, political, institutional, environmental and spatial aspect. The multidimensionality of the transition, is mostly expressed in the economy, especially in the industrial production as dominant in the economic structure of the country. The industrial enterprises were transformed in size and ownership, they experienced certain changes in the internal organization, they were the subject of market, production and technological transformation and sector transformation. It also indicated changes in the structure and the production model of the industrial development at national, regional and local level. Under the influence of the effects caused by the transition, the importance and quality of the location changed, reducing or limiting the pace of development of one and accelerating the development of other fields, guided by the intention to reduce regional disparities [3].

Given that in the structure of the industry for decades were prevailed some of the initial forms of industry, with the plans for structural organization and reorganization, the intentions were focused towards encouraging industries in which will be produced export products with higher added value. Such commitments were expected to be realized with foreign capital, which can be seen as an imperative in the restructuring of the economic entities. Such investments would enable the revitalization of production process and its restructuring, raising in the technological level of the production process, increased efficiency of the economy, in the function of export restructuring of the production and dimensioning of GDP [2]. At the same time, investments were expected to activate the workforce and the usage of natural resources and to enable transfer of technology and knowledge. The efforts were focused to attract investors to propulsive industrial branches, which will have a positive benefit on the operations of small enterprises in different regions at the same time. Their connection with investors in a horizontal and vertical sense is a priority in the further efforts to attract new FDI. 
The attempts to realize such an idea began with the promotion of the Republic of Macedonia through business forums (marketing campaigns - Invest in Macedonia and Macedonia Timeless) as a favourable business destination for foreign investors. With tax and customs benefits and purpose-built infrastructurally prepared locations, certain Greenfield investments were attracted (Investing in new facilities in an area where they did not exist until then). At the same time, certain so-called "Industrial fallow land", i.e. abandoned enterprises that were the victims of poor transformation and inadequate operation were put into operation for the realization of Brownfield investments (investing with the purchase of an existing facility in order to activate a new production activity). Some of the investments were in the form of acquisitions and mercenaries (transfer of the existing capital from the local domestic company to or from a foreign company [7]).

The penetration of foreign capital, which at the same time meant the possibility for a certain structural change within the industry, took place in several phases. Until 1998, enterprises were bought by employees or managers, so that from 1998 to 2003 a number of companies in the country were taken over by investors. In the coming years of the $21 \mathrm{st}$ century, intensive investments started, mainly from abroad targeted at certain sectors of the industry. In the period from 2003 to 2007, even $60 \%$ of the total investments were in the industry (6\% in the extractive industry, $25 \%$ in the processing and $29 \%$ in the supply of electricity, gas and water [4]). 2006 is considered as the year when a more intense wave of FDI started, that reflected the diversification of the industry in the country. The first major Greenfield investment was by Johnson Control in 2006, followed by more of the realized investments of foreign investors in the processing industry. In the period from 2003 to 2015 , almost $40 \%$ of the total investments in the country are in the industry, of which, $79.8 \%$ were in the processing industry, close to $2 \%$ in the extractive and $18.2 \%$ in the energy economy.

The foreign direct investments were more noticeable in some industries, among which the automotive industry is the most emphasized. The flow of FDI in the automotive industry till the end of 2014 was 449.9 million euros or $11 \%$ of the total FDI and nearly a third of the industry's investments.

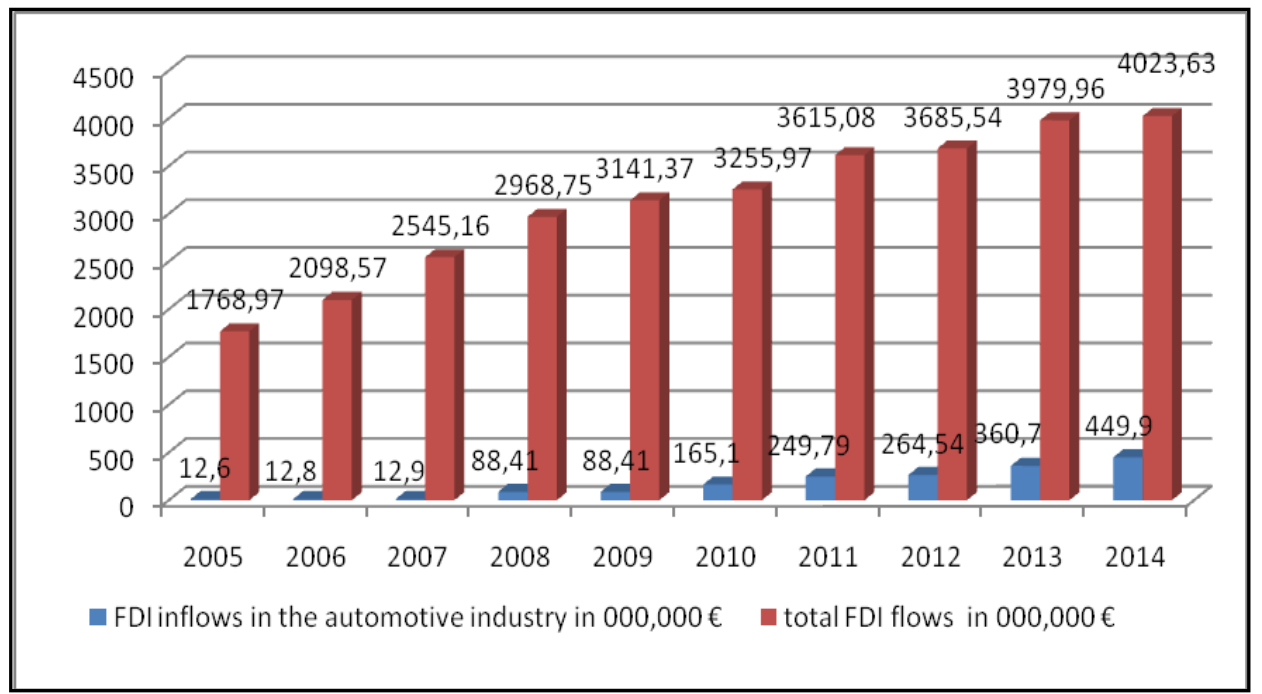

Figure 1: The total FDI inflows and FDI in the automotive industry. Source: [4]

FDI in this industrial sector dominated after 2007 and especially after 2009. So far, the investments are from the major multinational companies (Johnson Control, Johnson 
Matthey, TeknoHose, Kemet Electronics, Van Hool, ODV Electric, Markart, Draexlmaier, Kromberg \& Schubert). With the exception of Van Hool, which produces buses as a final product, all of the other investments belong to the first and second levels in the chain of creation of the final product in the automotive industry [6]. The higher level of finalization and complexity of FDI products is proportional to the increase in investments by local suppliers. An example is the Macedonian company Aktiva, whose production is connected to the Van Hool [6].

Most of the industrial workers are employed in the automotive industry. According the records, in 2014 of the total number of 10,890 persons employed in the newly-invested enterprises, almost $74 \%$ are employed in three factories from the automotive industry: Johnson Control - TIDZ Skopje, Kromberg \& Schubert and Draexlmaier - Kavadarci.

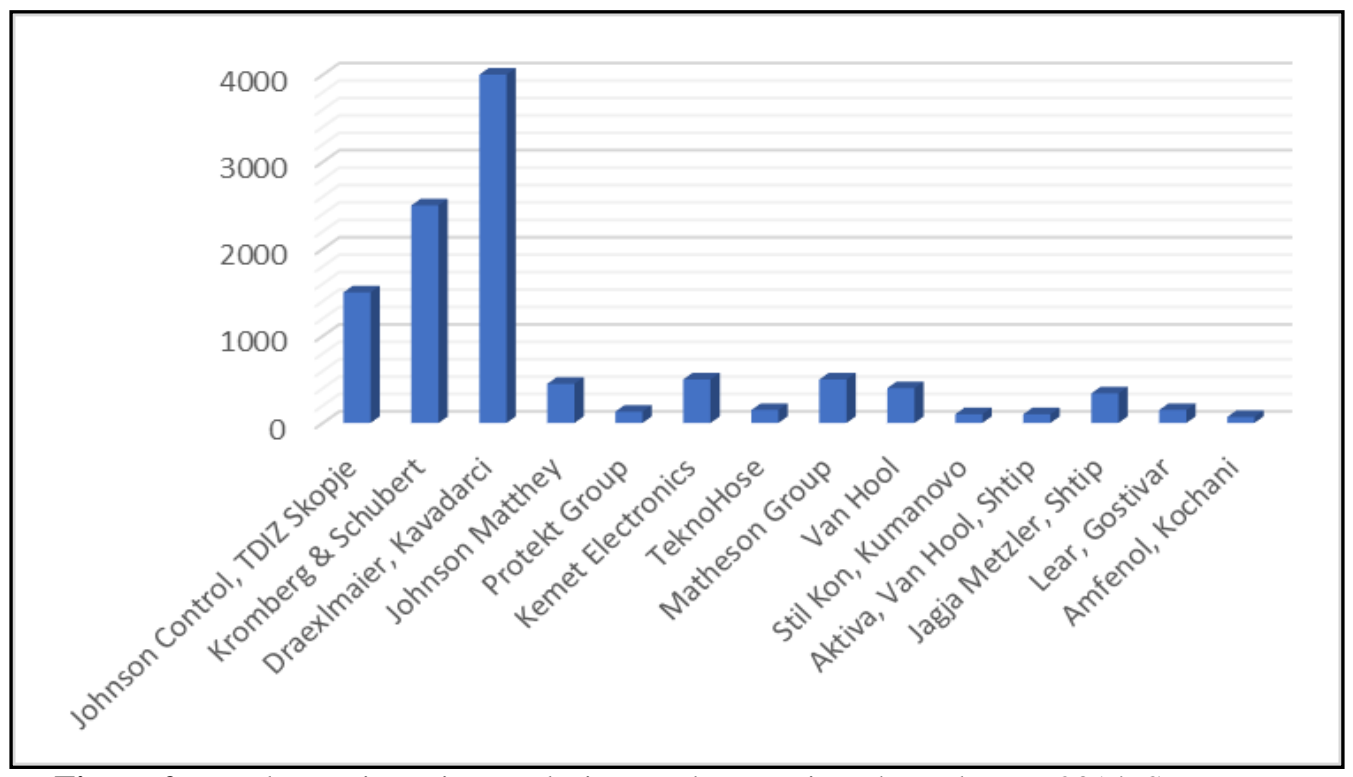

Figure 2: Employees in major newly-invested enterprises through FDI, 2014. Source: [7]

Although from the main industrial branches, the largest share in the total industrial production index has the non-performing products with $38.7 \%$, while the smallest share of the durable consumer goods group has accounted for $2.7 \%$, the share of capital goods in 2015 compared to 2010 increased by $10.8 \%$. The increase is mostly related to the startup of business entities in TIDZ.

In contrast to the previous period, especially until 2009, when the production indexes showed a sharp increase in the traditional industrial branches, and for which was emphasized that they are the carriers of the development [5], the index for the production of vehicles increased in the following years and in 2015 the production increased by more than 5 times compared to 2010 (index 561), followed by the production of machines and devices (index 439.4) and production of other equipment and transport (index 228.5). Thus, the influence of FDI implies a possible change in the future structure of the industry. At the same time, the structure of the industry in the Republic of Macedonia is still dominated by the traditional industries such as food industry, beverage industry, tobacco, textiles, basic metals and metal processing industry and non-metal minerals. In the period from 2000 to 2014, all of these industries together made an average of $66.6 \%$ of the Gross value added in the manufacturing industry. However, it is indispensable to note that some specific industrial sectors also show an increase in the total participation, such as 
pharmaceutical industry (especially after 2002), the electrical industry, the automotive industry and so on.

In the structure of industrial production, the increased participation of industrial branches in the order of production of motor vehicles, machines and devices, the production of electrical equipment, which have a significant share in the total export, is evident. In the period from 2010 to 2015, the export of goods registered an average annual increase of nearly $14 \%$. The participation in the export of goods with higher technological value was significantly increased due to the reduced share of exports of goods with lower levels of processing. In comparison, from 2005 to 2015, exports of machinery and transport equipment and chemical products registered a significant increase.

The industry is not just a physical object, but also has a strong economic and social dimension, with the possibility of urban, economic, demographic, social and sustainable development of the space at micro and macro level. With the proper location of the industry it can be provided a more appropriate use of the resources and potentials that exist or can be created, the forms of population and economic polarization and social tensions can be reduced. At the same time, it can be initiated the development of other activities in transport, trade and tertiary activities. According to the Law on twice the value of the workplace in the industry, the industry can overtake the role of spatial development coordinator. This is a sufficient reason for the industry to be placed in the role of an activity that will contribute to more balanced economic development. It is known that there is economic polarization on the territory of the Republic of Macedonia, which on the other hand entails demographic polarization and affects the overall socioeconomic development of the area. The main goal is to overcome the stereotype in the location of the industrial capacities in the Skopje region. This has brought many problems, especially regarding intense settlement in this region and its pollution. That is why during the organization of the industrial zones were made attempts for proper regional disposition, location and appropriate types of propulsive industrial branches. The 15 TIDZs (Skopje 1, Skopje 2, Skopje 3, Shtip, Tetovo, Prilep, Struga, Strumica, Kishevo, Gevgelija, Berovo, Delchevo, Radovish, Rankovce and Vinica), that were established, represent customs and tax-free zones with an appropriate infrastructure equipment. Among them, TIDZ Skopje 1, Skopje 2 and Shtip are fully operational, while for TIDZ Tetovo, a Public Private Partnership Agreement with an international company has been signed. Investments are also expected in the areas that are not fully functioning, so that the initial idea of reducing the developmental disparities at the territory of the Republic of Macedonia and ensuring the overall sustainability of the area can be achieved.

\section{CONCLUSION}

The structure of the industry in the Republic of Macedonia is mainly based on traditional industrial branches that have the largest share in the gross added value of the processing industry. FDI that entered into the Macedonian industry at the end of the last century and the beginning of the $21^{\text {st }}$ century contributed to some industrial branches to emphasize their place in the structure of industrial production. 


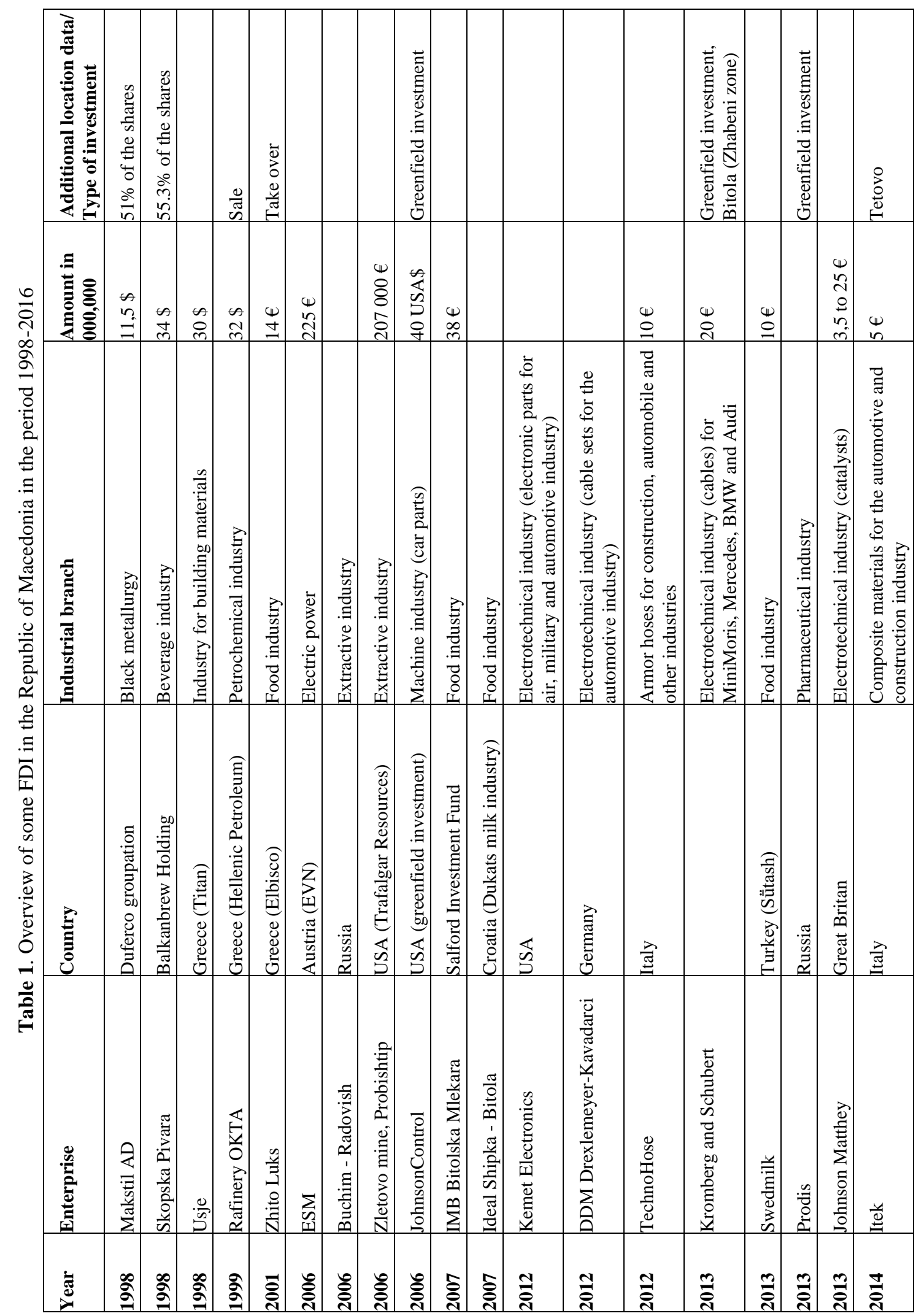




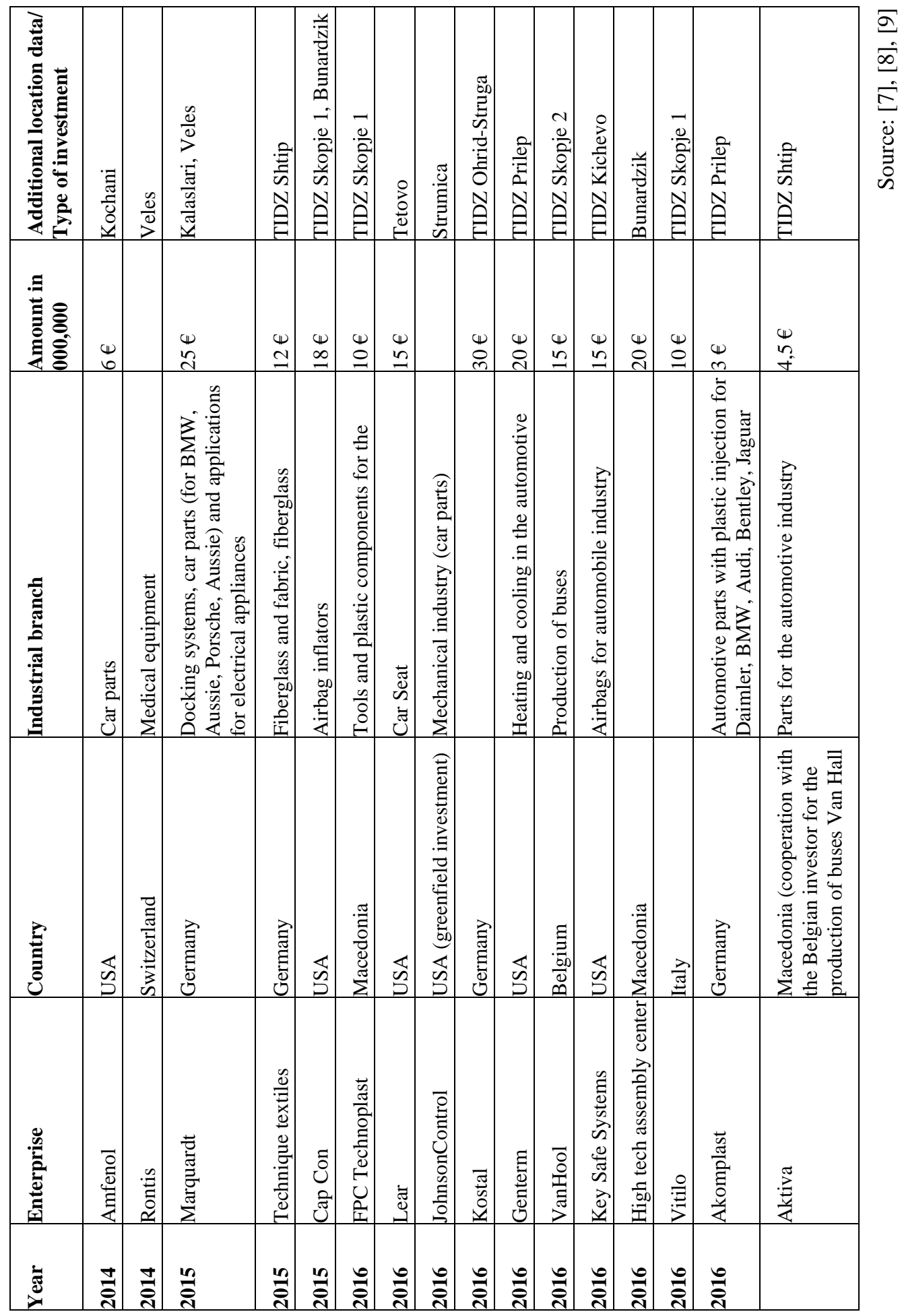

In fact, the FDI is the product of a package of stimulative and subsidized measures and policies for foreign investors, located mainly in the TIDZ. Among them, more pronounced are the investments in the automotive industry. Specifically, in this industry were invested $11 \%$ of the total FDI and a third of the investments in the industry. We are talking about 9 major automotive companies. Only in Johnson Control - TIDZ Skopje, Kromberg \& Schubert and Draexlmaier - Kavadarci were employed about $74 \%$ of the total number of persons employed in the newly-invested enterprises. 
Their spatial distribution was focused on achieving more balanced economic development in the country. FDI as an attempt for structural and spatial reorganization of the industry in the Republic of Macedonia is an expensive project by the Government. Therefore, the long-term viability of the project is expected.

So far, over 500 Macedonian companies benefit from the incomparable cooperation, and there is a turnover of about 50 million euros for the companies that cooperate with foreign investors [7]. At the same time, it meant an opportunity for starting companies that provide certain services to the new formed companies. In fact, all enterprises that are the result of FDI in the Republic of Macedonia should establish strong horizontal and vertical ties with domestic companies, that depends on the technological level of the domestic companies, their orientation towards innovation and the availability of a quality workforce. At the same time, it is more than necessary to consider FDI as a way of changing the structure of the industry by producing products with higher value added.

At the same time, parallel to the foreign investments, it is necessary to create favorable conditions and equal opportunities for investments by the domestic investors.

\section{REFERENCES}

[1] Apostolovska Toshevska B. Industry and sustainable development. Proceedings of the scientific symposium with international participation, Geography and sustainable development, held in Ohrid, 20-25.10.2009, pp. 253-267, 2009.

[2] Blazevski B. Foreign capital in function of the technological development of the Republic of Macedonia. Papers and discussions from a scientific gathering held on March 20, 2003.

[3] Miletić R., Miljanović D. \& Todorović M. Industrial Cities in Transition - Problem Areas. Herald by the Serbian Geographical Society, Vol. LXXXIX (3), pp. 191-206, 2009.

[4] NBRM. Report on the Direct Investments by activities, 1997-2003, 1997-2005, 20102014.

[5] Nestorovski M. The level of development of the structure, investments and export efficiency of the processing industry in the Republic of Macedonia, Yearbook of the Faculty of Economics, Vol. 46, pp. 135-152, 2011.

[6] Petkovski V. \& Damoska Sekulovska J. Analysis of the degree of connection between FDI and domestic suppliers through the example of the automotive industry in the Republic of Macedonia, Yearbook of the Faculty of Economics, Vol. 51, pp. 297-310, 2016.

[7] Popovska M. Statistical performances on the influence of foreign direct investments in the capital market with a special focus on the Republic of Macedonia, Master thesis, University "Ss. Kliment Ohridski" - Bitola, Faculty of Economics - Prilep, 2016.

[8] SSORM. Foreign Direct Investments in the Republic of Macedonia (2003-2007), 2009.

[9] SSORM. Industry 2011-2015, Statistical review: Industry and energy, 6.4.16.01.846; www.stat.gov.mk.

[10] Stojmilov A. \& Apostolovska Toshevska B. Socioeconomic geography of the Republic of Macedonia, Faculty of Natural sciences and mathematics, Skopje, 2015.

[11] Uzunov H. Basic features of the industrial development in the P.R. Macedonia, Yearbook of the Faculty of Economics, Vol. VII, 1960.

[12] Uzunov H. The economy in the Republic of Macedonia 1945-1990, MASA, 2001. 